\title{
Largo da Banana e a presença negra em São Paulo'
}

\author{
Largo da Banana and black presence in São Paulo's history
}

https://doi.org/10.1590/1982-02672020v28d le9

\section{RENATA MONTEIRO SIQUEIRA²}

http://orcid.org/0000-000 1-9537-2795

Universidade de São Paulo / São Paulo, SP, Brasil

RESUMO: $\bigcirc$ Largo da Banana está associado à história da população negra em São Paulo. Reconhecido como um dos "berços" do samba paulista, é sobretudo através dos próprios sambistas que essa história pode hoje ser conhecida. Localizado junto à antiga estação da Barra Funda, desde as primeiras décadas até meados do século passado, aquele espaço concentrou trabalhadores informais vinculados às atividades da ferrovia. Em meio a um cotidiano precário e instável, essa população realizava rodas de samba e de tiririca. Nos anos 1950, foi construído naquele local o Viaduto Pacaembu, que prolongava a avenida homônima para além da via férrea. A partir da década de 1960, o sambista negro Geraldo Filme compôs duas canções em que homenageava o Largo da Banana e lamentava seu desaparecimento após a inauguração do viaduto. Nessas e em outras composições, o artista registrou suas percepções sobre as condições de vida da população negra e sambista na cidade, suas sociabilidades, bem como sobre as transformações urbanas que testemunhou. Considerando que sua obra artística contribui para iluminar aspectos da realidade social, ela é adotada como fonte para analisar as formas de sociabilidade no Largo da Banana e a intervenção urbanística naquele local.

Palavras-Chave: Largo da Banana. Barra Funda. Viaduto Pacaembu. Negros em São Paulo. Geraldo Filme.
1. Este artigo apresenta resultados de uma pesquisa de doutorado em andamento na FAU-USP, com apoio da Fapesp (Processo n²016/26239-8). Agradeço a leitura e as contribuições de minha orientadora, Ana Cláudia Castilho Barone (FAU-USP), e dos professores Brodwyn Fischer (University of Chicago) e José Tavares Correia de Lira (FAU-USP). Do mesmo modo, sou grata aos pareceristas anônimos que avaliaram este artigo, pelas suas generosas observações. Também agradeço a Filipe Amado por compartilhar a entrevista de Tio Mário, sambista e trabalhador do Largo da Banana, e a Bruno Nogueira por colaborar com a formatação da imagem incluída neste artigo.

2. Doutoranda em História de Arquitetura e Urbanismo pela Universidade de São Paulo (USP). Pesquisadora do Laboratório de Estudos sobre Relações Étnico-Raciais e o Espaço Urbano, Labraça, na Faculdade de Arquitetura e Ur- 
banismo da USP. E-mail: $<$ renata.siqueira@usp.br>.
ABSTRACT: The Largo da Banana relates to the history of the black population in São Paulo. Acknowledged as one of São Paulo's "cradle" of samba, samba musicians are its main spokespersons. Largo da Banana used to be located near the former Barra Funda Railway Station. From the first decades to around half the Twentieth century, informal laborers in the railway logistics used to gather together in that space. Within a precarious and unsteady daily life, they used to play samba and tiririca. In the fifties, the municipality built the Pacaembu Viaduct in that area, aiming to extend the homonym avenue beyond the railway road. In the sixties, samba musician Geraldo Filme wrote two songs in which he paid homage to Largo da Banana and regretted its disappearance after the viaduct's inauguration. In these and other of his songs, the artist recorded his perceptions on the life conditions of São Paulo's blacks and samba musicians, their sociabilities, and also the urban changes he witnessed. Considering that his artistic work contributes to enlighten aspects of social reality, I analyze some of his songs to interpret the sociabilities at Largo da Banana, as well as the urban intervention in that location.

Key-words: Largo da Banana. Barra Funda. Pacaembu Viaduct. Blacks in São Paulo. Geraldo Filme. 
O LARGO DA BANANA COMO ESPAÇO DA POPULAÇÃO NEGRA EM SÃO PAULO

\author{
Vou sambar n'outro lugar \\ Fiquei sem o terreiro da escola \\ Já não posso mais sambar \\ Sambista sem o Largo da Banana \\ A Barra Funda vai parar \\ Surgiu um viaduto, é progresso \\ Eu não posso protestar \\ Adeus, berço do samba, \\ Eu vou-me embora \\ Vou sambar n'outro lugar
}

Na canção "Vou sambar n'outro lugar", de Geraldo Filme (1927-1995), um sambista lamenta o desaparecimento do Largo da Banana após a construção do Viaduto Pacaembu na Barra Funda, São Paulo, em 1958. Gravada nos anos 1970 em um trabalho em parceria com o dramaturgo Plínio Marcos, a canção era parte de uma narrativa sobre a história do samba na cidade de São Paulo e seus deslocamentos pelo espaço urbano. ${ }^{3} \bigcirc$ viaduto, representando a chegada do progresso, acarretara o fim do samba na Barra Funda, levando à necessidade de buscar outros espaços para sambar. Dessa forma, a canção instiga a refletir sobre o processo de urbanização em curso naquele período e como esse foi percebido por sambistas, representando uma população majoritariamente negra e pobre. Qual seria a visão do eu lírico acerca do fenômeno do progresso? Seria possível pensar em samba e progresso como esferas compatíveis, ou seriam elas sempre antagônicas? deslocamento do sambista seria resultado de um processo de expulsão ou de uma decisão deliberada e resistente contra um projeto de urbanização excludente?

O Largo da Banana localizava-se nas imediações da estação de trem da Barra Funda, importante centro de abastecimento da cidade, bem como um entreposto para as mercadorias que se destinavam ao porto de Santos do interior do estado. ${ }^{4}$ Conta-se que esse nome foi-lhe atribuído informalmente em função dos gêneros que chegavam por trem e lá eram comercializados, também informalmente, por trabalhadores, muitos deles negros e mestiços, que carregavam e descarregavam produtos nos armazéns ao redor da estação. ${ }^{5}$ Nos intervalos do trabalho precário e incerto, eles realizavam rodas de samba e de tiririca. Embora a localização do Largo da Banana não esteja indicada nos mapas da cidade, ele se encontrava entre as ruas Brigadeiro Galvão, Barra Funda, Cadete
3. A canção foi incluída na trilha sonora de dois espetáculos de Plínio Marcos nos anos 1970. Em "Balbina de Iansã" (1971), a canção foi apresentada sob o nome de "Terreiro da Escola". A peça narrava as disputas entre terreiros de candomblé e suas famílias de santo, inspirada no clássico shakesperiano "Romeu e Julieta" e em crônicas cotidianas (Marchezin, 2016, p.34). Sob o nome de "Vou sambar n'outro lugar", a canção integrou o espetáculo "Humor grosso e maldito nas quebradas do mundaréu" (1973), que cantava a história do samba paulista. A obra alternava narrações do dramaturgo com músicas de Geraldo Filme, Zeca da Casa Verde e Toniquinho Batuqueiro (Id., p.41). O novo título é sintomático da mudança de foco de um trabalho para o outro. Na peça de 1971, a ideia de terreiro remetia ao universo do candomblé em que a trama se desenvolvia, enquanto aquela de 1973 focava-se nos deslocamentos dos espaços de samba pela cidade.

4. Desde o final do século XIX, a Barra Funda abrigou as estações da Companhia Sorocabana e da São Paulo Railway. No início do século $\mathrm{XX}$, a Sorocabana lá instalou o seu pátio de cargas e manobras, que, entre outras funções, permitia armazenar as mercadorias que chegavam por aquela companhia do interior para serem transferidas à São Paulo Railway com destino ao porto de Santos (Soukef Jr., 2001, p. 29). Em 1932, a estação da Barra Funda era a de maior movimentação de exportações e importações na cidade de São Paulo. Ricardo Junior (1932, p.125).

5. Cf. Souza (1981), Nazaré (1981), Barbosa (1976) (documentos audiovisuais); Gomes da Silva (1990, p.58); Britto (1986, p.39) 
6. A definição dessa localização resulta da análise da documentação relativa ao projeto do Viaduto $\mathrm{Pa}$ caembu no acervo da Prefeitura Municipal de São Paulo e de depoimentos concedidos por antigos sambistas, especialmente Geraldo Filme, Dionísio Barbosa e José Narciso de Nazaré (Zezinho da Casa Verde), que integram a coleção "Carnaval Paulistano" do Museu da Imagem e do Som de São Paulo. Cf.Silva (2018) e Gomes da Silva (1990).

7. Borin (2014, p.18).

8. Como observam Gomes da Silva (1990, p. 47) e Moraes (1997, p.30).

9. Rolnik (2003, p.61).

10. Moraes, (1997, p.62).

11. Id., p.42, grifo nosso. e a Alameda Olga (figura 1). ${ }^{6}$ Esse terreno foi destinado à construção do Viaduto Pacaembu, que prolongava a avenida homônima para além dos trilhos, estabelecendo a conexão com a Ponte da Casa Verde, sobre o rio Tietê, e, futuramente, com as marginais expressas que acompanhariam seu curso.

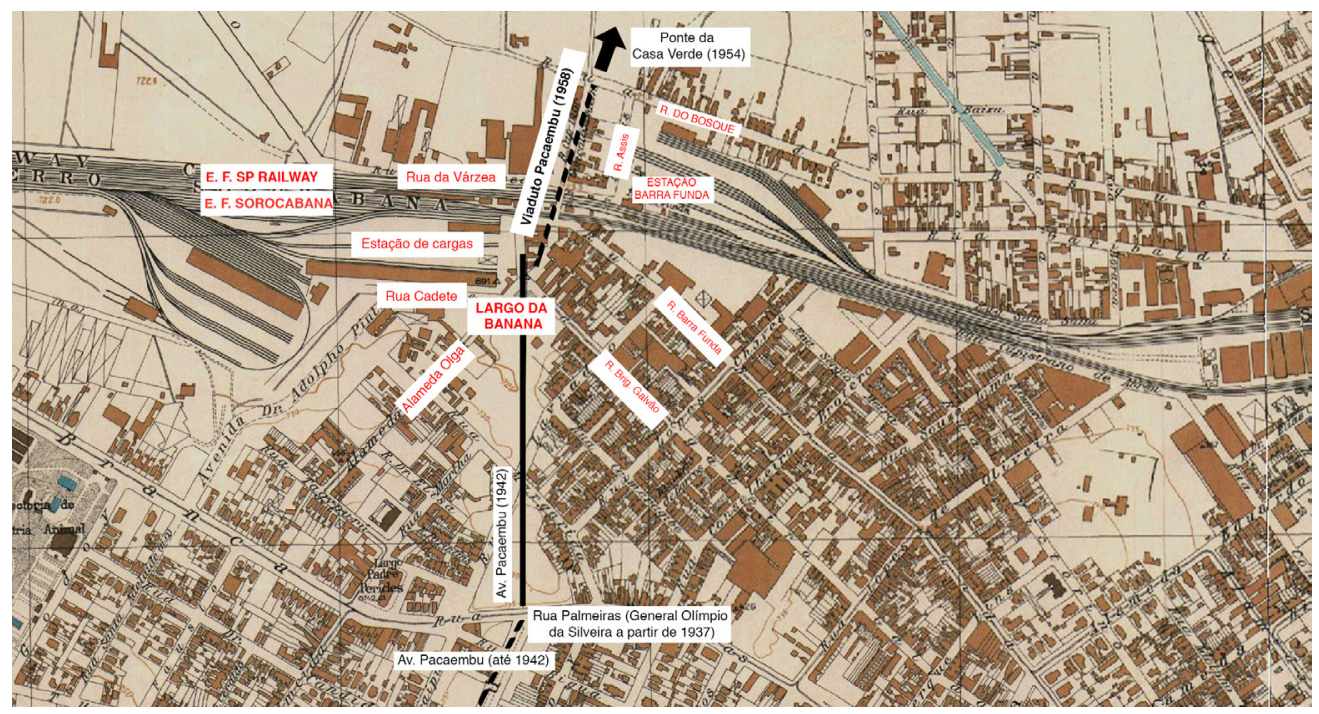

Figura 1 - Localização do Largo da Banana, antes da construção do Viaduto Pacaembu, sobre mapa elaborado pelo consórcio Sara-Brasil em 1930. Fonte: Geosampa, 2018.

O Largo da Banana conformava um território popular e de trabalho, embora vizinho às mansões e palacetes erigidos no mesmo bairro. A Barra Funda, desde o final do século XIX, caracterizou-se por uma ocupação mista, tanto em termos de usos como de classe social e de raça, como observou a historiadora Monique Borin.? Assim como em outros espaços populares da cidade, parte significativa dos habitantes da Barra Funda eram imigrantes brancos pobres ou negros e mestiços, também pobres, refletindo-se na presença de elementos da cultura afro-brasileira que lá se desenvolveram. ${ }^{8}$ As formas de moradia, de trabalho e de lazer dessa população tenderam a ser consideradas ilegais, porém relativamente toleradas, conformando o campo da informalidade urbana, como argumentou Raquel Rolnik. ${ }^{9}$

Autores interessados nos grupos populares em São Paulo destacaram a condição de marginalização que resultava dessa situação. José Geraldo Vince de Moraes, por exemplo, assinalou que nas primeiras décadas do século XX os pobres urbanos ocuparam os espaços que ficavam à margem dos projetos urbanísticos implementados. ${ }^{10} \bigcirc$ autor reforça que em tais espaços esses setores da população pareciam viver em uma cidade "completamente diferente, escondida e distanciada daquela que se formava com ares europeus". "Isses 
grupos precisavam criar modos informais de sobrevivência e de produção e reprodução de suas experiências culturais, geralmente nas ruas, quintais e festas populares. ${ }^{12}$ leda Marques Britto, defendendo que o samba constituiu, naquele período, um exercício de resistência cultural negra, observou que carregadores e ensacadores nos armazéns paulistanos foram os principais responsáveis pela construção da "legenda" do samba do Largo da Banana. ${ }^{13}$ Para a autora, esses sambistas constituíam o grupo de trabalhadores com menor qualificação, a quem "só restava a possibilidade de venda da sua força física". ${ }^{14}$ Não podendo ou não desejando ajustar-se à ordem social, esses homens eram vistos como transgressores. ${ }^{15}$ Embora Britto esteja interessada na dimensão política do samba realizado no Largo da Banana, a resistência cultural, para essa autora, permanece no âmbito de uma recusa aos valores dominantes e de uma retirada da sociedade. $\bigcirc$ Largo da Banana seria, assim, um "território livre", não sujeito aos controles exercidos no resto da cidade. ${ }^{16}$ Tais interpretações propõem que a população negra e mais pobre de São Paulo teria historicamente ficado à margem tanto dos espaços urbanos quanto da sociedade, desenvolvendo formas de sociabilidade alternativas. Britto, ademais, argumenta que isso decorria ou de uma escolha deliberada ou de uma incapacidade de ajustamento e que não havia interesse em participar politicamente - ou de outra forma - da ordem social mais ampla.

Interessado na vida pública da população negra no início do século XX, José Carlos Gomes da Silva estudou as dinâmicas de trabalho dos "chapas" (carregadores) dos armazéns próximos à estação da Barra Funda. $\bigcirc$ pesquisador também investigou o cotidiano de lazer desses trabalhadores, marcado pelo samba e pelos botequins, no Largo da Banana. Embora Gomes da Silva enfatize o sentido político das práticas culturais daquela população, para ele essas não eram parte de um projeto conscientemente elaborado, mas resultavam de uma ação cultural e política informal. ${ }^{17}$ Petrônio Domingues contribui para problematizar essa interpretação em sua reconstituição histórica do Cordão Carnavalesco Campos Elyseos, fundado em 1919 na Barra Funda, nas imediações do Largo da Banana. $\bigcirc$ autor revela que, assim como outros âmbitos de ativismo negro do período considerados mais "organizados" ou "politizados", como associações, clubes recreativos ou a Imprensa Negra Paulista, aquela instituição cultural também tinha uma preocupação com a "elevação moral" de seus participantes. Como mostra o historiador, o cordão propunha ações destinadas a ampliar a respeitabilidade de seus membros, contribuindo com os esforços de ressignificação da imagem pública e de valorização dos negros. ${ }^{18}$

As ações do Campos Elyseos constituíam formas de resistência social, mesmo que não fosse uma guerra aberta ao sistema, "quando [o cordão carnavalesco] demarcava posição na esfera pública, (re)elaborava e positivava fronteiras identitárias,
12. Id., p.33.

13. Britto, (1986, p.39-40)

14. Ibid

15. Id., p.91.

16. Deve-se ponderar que a condição de informalidade $\mathrm{e}$ a ocupação popular não repercutem, necessariamente, na formação de territórios segregados. Em uma análise centrada no conceito de "território negro", Raquel Rolnik e José Carlos Gomes da Silva assinalaram que em São Paulo, a segregação racial não correspondeu ao isolamento da população negra no território. Partindo de outros pressupostos e problematizando as representações da Barra Funda tanto como bairro "operário" como de "elite", o trabalho mais recente de Monique Borin enfatizou sua ocupação mista nas primeiras décadas do século XX. Rolnik (1989); Gomes da Silva, op.cit.,p.16; Borin, op.cit. p.63.

17. Gomes da Silva, op. cit., p.3.

18. Domingues (2013, p.136). 
19. Id., p.139.

20. Id., p.133.

21. Azevedo (2006, p.53).

22. Cf. Ciscati (2003); Cunha (2011); Oliveira Santos (2015).

23. Silva, (2018, p.8).

24. Id., p.14.

25. Em periódicos, a aparição de referências ao Largo da Banana inicia-se na década de 1950. Em 1953, o nome "Praça da Banana" consta no processo da Câmara Municipal como área em desapropriação para a construção do Viaduto Pacaembu. Cf. Correio Paulistano, 17 mar. 1953; Câmara Municipal de São Paulo, Processo n ${ }^{\circ}$ 929/1953. colocava em circulação retóricas raciais e ostentava performances, símbolos e artefatos afro-diaspóricos obliterados, quando não renegados, em São Paulo no período da Primeira República". ${ }^{19}$ Quanto à participação dos frequentadores do Largo da Banana nas atividades do grupo, Domingues assinala que trabalhadores subalternos, informais e braçais eram maioria entre os integrantes do bloco. Entre eles, carregadores, vendedores ambulantes, carroceiros, motorneiros, serventes de pedreiros, operários, funcionários públicos, além de outros atuantes nos serviços domésticos e burocráticos, em posições de baixo escalão. ${ }^{20}$ Tendo em vista essas ocupações profissionais e a inserção do grupo carnavalesco na Barra Funda, há indícios de que uma parcela, ao menos, dos trabalhadores informais do Largo da Banana participou das atividades daquela organização cultural e foi mais politizada do que a historiografia tendeu a reconhecer. No Campos Elyseos, tais trabalhadores tiveram oportunidade de debater sobre as condições de vida da população negra paulistana e podem ter vislumbrado outras formas de inserção social além da recusa em integrar-se. É também o que sugere Amailton Magno Azevedo, quando destaca que entre as décadas de 1920 e 1930 os negros do Largo da Banana se tornariam "protagonistas de sua própria história", conformando um espaço de desenvolvimento do samba que o autor comparou, em importância, à Praça Onze, no Rio de Janeiro. ${ }^{21}$

Em estudos mais recentes sobre cultura popular em São Paulo, o Largo da Banana costuma aparecer como um lugar de referência, muitas vezes com base nos trabalhos de autores como Britto e Gomes da Silva. ${ }^{22}$ Assim, é possível afirmar que, embora restrito ao meio interessado na cultura popular paulistana, o Largo da Banana é reconhecido como parte da memória urbana da população negra no início do século passado. Todavia, no âmbito dos estudos urbanos e da urbanização, mais atenção merece ser dada à história daquele espaço. Como observou Marcos Virgílio da Silva, "o lugar parece mais importante para a memória do samba do que da urbanização, e somente trabalhos voltados à história do bairro parecem dedicar alguma atenção ao lugar". ${ }^{23}$ Refletindo sobre a construção do Viaduto Pacaembu como parte de processo de planejamento autoritário e norteado pela visão rodoviarista, Silva reconheceu na obra de Geraldo Filme a principal forma de protesto contra a intervenção urbana que levou ao desaparecimento do Largo da Banana. ${ }^{24}$

A história do Largo da Banana está atravessada por inúmeros silêncios e informações desencontradas, que parecem relacionar-se com sua condição de informalidade e sua ocupação popular e negra. Não apenas o Largo da Banana não chegou a ser identificado na cartografia urbana, como tampouco parecem existir registros escritos, como artigos de jornais ou documentos oficiais, que façam referência àquele espaço até as vésperas da construção do Viaduto Pacaembu. ${ }^{25}$ Ao esquecimento do Largo da Banana, corresponde o das práticas socioculturais 
que lá eram realizadas, a exemplo da tiririca, um jogo de roda associado ao samba e semelhante à capoeira. Essa atividade parece ter desaparecido das ruas de São Paulo na segunda metade do século passado e, a não ser por depoimentos e registros realizados por alguns de seus praticantes ou testemunhas, pouco se sabe sobre ela atualmente. ${ }^{26}$ Mário de Andrade, que viveu na Barra Funda entre 1921 e 1945, a despeito de seu interesse pela cultura popular e de suas contribuições nesse domínio, não escreveu sobre manifestações culturais que tenham ocorrido no Largo da Banana. ${ }^{27}$ Nesse sentido, a recuperação histórica do Largo da Banana implica identificar formas de sociabilidade que lá existiram e que fizeram parte da realidade urbana paulistana, de modo mais amplo.

Os sambas compostos por Geraldo Filme e os depoimentos de antigos sambistas de São Paulo, todos posteriores ao viaduto, estão entre os principais documentos que permitem contar a história daquele espaço atualmente. A partir de sua obra, propomos no presente artigo investigar as sociabilidades populares negras do Largo da Banana, bem como a percepção sobre a intervenção urbanística naquele espaço. ${ }^{28}$ Em suas canções, o sambista negro, que cresceu na Barra Funda, valorizou a cultura e as contribuições da população negra para a sociedade e denunciou as iniquidades que recaíram sobre eles, em especial sobre os sambistas. ${ }^{29}$ As canções desse artista permitem identificar dissonâncias em relação às narrativas hegemônicas sobre o processo de modernização e de metropolização, especialmente por abordar seus efeitos sobre a população negra e sambista da cidade. Analisamos não apenas as letras que remetem diretamente ao Largo da Banana, mas um conjunto mais abrangente que permite refletir sobre questões gerais que repercutiram naquele processo, tais como aspectos das práticas culturais realizadas no Largo da Banana, a caracterização de sua população, as percepções sobre as transformações da cidade e o aparente antagonismo entre samba e progresso. Essa perspectiva analítica apoiase na ideia de que a forma artística se refere tanto à análise dos elementos que estruturam determinada obra quanto à interpretação do sentido de tal estrutura à luz do processo histórico. ${ }^{30}$ Nesse sentido, obra e realidade social iluminam-se mutuamente. Procuramos compreender o movimento cultural do samba e nos aproximarmos de seus "produtos" enquanto fonte de pesquisa a partir da acepção polissêmica do termo "cultura", articulando desenvolvimento intelectual, artístico e modos particulares de vida. ${ }^{31}$ Assim, o samba é compreendido como um movimento intelectual e social que resulta em uma produção artística, cuja importância é ampliada pelo fato de corresponder a um modo de vida de um grupo social que vive e transita pela cidade de São Paulo. Essa opção metodológica não advém da escassez de outros tipos de fontes relativas ao Largo da Banana, embora isso também seja um fato, mas orienta-se pela valorização do meio cultural onde se gestou a construção de sua memória.
26. A prática da tiririca em São Paulo e suas relações com o samba e a capoeira tem sido objeto de estudos recentes. Cf. Amado (2019); Oliveira Santos (2015); Cunha (2011). Na década de 1970, Wilson Rodrigues de Moraes também publicou registros dessa prática na cidade e na Barra Funda. Cf. Moraes (1978).

27. É o que observou Gomes da Silva, (1990, p.32). Isso também chamou a atenção do escritor João Antônio em O Estado de S.Paulo, 29 nov. 1986, p.91.

28. Para outras perspectivas analíticas da obra de Geraldo Filme, cf. Azevedo (2006); Silva (2011); Conti (2011); Prado (2013); Marchezin (2016). Tais trabalhos incluem análises biográficas e da trajetória do artista. Nesses estudos, não apenas o conteúdo das letras é objeto de análise, mas também a forma musical. Reconhecemos a imensa perda em não analisar os aspectos musicais desse tipo de documento, o que demandaria o domínio de um campo de conhecimento que a pesquisadora não possui. Alguns aspectos musicais foram incorporados à nossa reflexão com base em fontes secundárias.

29. Semelhante ao que ocorre com o Largo da Banana, a memória de Geraldo Filme ficou circunscrita ao meio dos interessados no samba de São Paulo, como aponta Prado (2013, p. 103). Sua trajetória, biografia e obra é marcada por imprecisões. Tendo gravado um único álbum autoral em 1980, quando já tinha mais de 50 anos, é difícil, por exemplo, conhecer a data de suas composições.

30. Garcia (2010, p.110).

31. Willams, (2007, p.122). 
32. Gomes da Silva, op. cit., p.71.

33. Ferreira dos Santos (1998, p.57).

34. Borin, op. cit., p.30.

35. Id., p. 115.

36. Souza, 2000(documento audiovisual).

37. Ibid
Buscando identificar, a partir das letras de samba, o modo como o processo de urbanização foi percebido, pretende-se questionar uma narrativa dicotômica sobre a modernidade paulistana, em que os negros e seus espaços na cidade corresponderiam ao arcaico, primitivo ou, no melhor dos casos, ao "tradicional", ameaçados pelo progresso e eventualmente eliminados por este. Sugerimos, ao contrário, que se estabeleceu uma relação ambígua com a noção de progresso, atravessada por um desejo de reconhecimento enquanto sujeito social e de participação nas vantagens dele advindas. José Carlos Gomes da Silva chama a atenção para o fato de que símbolos culturais não são, em si próprios, arcaicos ou modernos, nem são normais ou anômicos. Eles podem ser manipulados de formas diversas por distintos grupos sociais, de modo que seus significados não são fixos, mas modificam-se segundo o contexto. ${ }^{32}$ Carlos José Ferreira dos Santos questionou a noção de que os trabalhadores nacionais não-brancos estiveram à margem do processo de modernização paulistana na virada do século XIX para $\circ$ XX. pesquisador defendeu que, embora ocultados e repudiados pela narrativa dominante, esses trabalhadores foram fundamentais para viabilizar a modernização em curso..$^{33}$ Por outro lado, Borin também observou que o crescimento urbano, que movimentou intensamente a economia no início do século XX, calcou-se sobretudo nos setores médios e empobrecidos, que financiaram "a construção concreta e simbólica da modernidade das elites paulistas urbanas". ${ }^{34}$ Ao mesmo tempo, a implantação de um determinado tipo de projeto de modernização europeizada foi dificultada por práticas de resistência da população pobre. ${ }^{35} \mathrm{~A}$ análise das sociabilidades no Largo da Banana e da percepção acerca da intervenção urbana sobre aquele espaço nos anos 1950 adota esse conjunto de problematizações como perspectiva.

\section{SOCIABILIDADES NEGRAS NO LARGO DA BANANA}

Geraldo Filme conta que descobriu o Largo da Banana na infância quando, por volta de 1937, entregava as marmitas preparadas pela mãe pela cidade. Nesses deslocamentos, "atravessou a fronteira" dos casarões dos Campos Elísios para a várzea da Barra Funda, onde conheceu "a negrada" do Largo da Banana. ${ }^{36}$ Seus relatos reiteram a ideia de que a sociabilidade do samba acontecia no intervalo do trabalho: "[...] Lá no largo da Banana, na hora que folgavam um pouquinho, eles armavam um samba e a gente era moleque, ficava olhando os velhos [...]. A gente ficava apreciando 'os coroas' todos cantar e a gente guardou muita coisa e deu continuidade" ${ }^{37}$ Outros sambistas negros também relembram ter 
frequentado o Largo da Banana durante a infância e juventude. Toniquinho Batuqueiro (1929-20 1 1), por exemplo, ia ao Largo da Banana durante a década de 1940, segundo conta, porque aquele era um local de passagem em seus percursos a pé entre o centro, onde engraxava sapatos, e sua casa, no bairro do Peruche. Quando tinha fome, parava no Largo da Banana. Segundo ele, "o Largo da Banana tinha samba né, ao mesmo tempo que eles vendia banana, comia banana, tava sempre de barriga cheia, jogava suas tiririca, os compositores reunia ali, cada um tirava um verso, quer dizer, tirava um samba né $[\ldots]^{\prime \prime}{ }^{38}$

A Barra Funda é frequentemente mencionada em estudos sobre São Paulo como um importante lugar de concentração negra e de reprodução da cultura afrobrasileira, especialmente nas primeiras décadas do século XX. ${ }^{39}$ Depoimentos de pessoas que conheceram a Barra Funda em décadas posteriores, como Geraldo Filme, Toniquinho Batuqueiro, Carlão do Peruche ou Tio Mário indicam que essa característica permanecia ao aproximar-se a metade do século. ${ }^{40}$ Para José Carlos Gomes da Silva, parte significativa dos negros que se dirigiram ao bairro eram migrantes de áreas rurais que foram para lá atraídos pela possibilidade de alugar os porões do casario do bairro ou cômodos em cortiços, onde formaram territórios coletivos de sociabilidade. ${ }^{41}$ Além da moradia, as possibilidades de trabalho constituíam um importante atrativo para essa população. Por um lado, o bairro tinha fácil acesso a áreas de residência da elite paulistana, como Santa Cecília, Higienópolis, Campos Elísios e outras partes da própria Barra Funda. A dinâmica da estação de trem também apresentava muitas oportunidades, tais como alinhar os vagões no pátio de manobras das companhias ferroviárias e executar o trabalho braçal nos armazéns de café, de gêneros alimentícios que abasteciam a cidade, entre outras mercadorias. $O$ trabalho nos armazéns era estafante e os carregadores, contratados informalmente e pagos por tarefa, apressavam-se em terminar o serviço para, assim, ampliar seu tempo livre.42 Tio Mário, um antigo trabalhador dos armazéns ao redor do Largo da Banana, relembra a dinâmica precária daquela função e o modo como essa estava vinculada ao samba. Segundo suas rememorações, os carregadores se reuniam em torno de uma pedra aguardando as oportunidades de trabalho, a cada dia. Quando não havia serviço, dizia-se que a pessoa estava "na pedra". Sem trabalho, não havia dinheiro sequer para comprar uma marmita de 500 réis no bar da esquina, de modo que ou pediam-se restos, ou ficava-se sem comer. Nesse mesmo bar, tocavam samba. Esse depoimento revela um cotidiano de trabalho intermitente, de precariedade, mas também de solidariedade e de lazer, com a realização de rodas de samba. ${ }^{43}$ No Largo da Banana, Tio Mário gostava de assistir às rodas de tiririca, embora não gostasse de jogar. $\bigcirc$ carregador e integrante da bateria da escola de samba Camisa Verde também relembra ter
38. Apud Oliveira Santos (2015, p. 173).

39. Cf. Rolnik (2003); Moraes (1997); Britto (1986); Gomes da Silva (1990); Oliveira (2008); Domingues (2013), entre outros.

40. Os depoimentos de Geraldo Filme analisados neste artigo foram extraídos de sua entrevista para o programa "Ensaio" apresentado pela TV Cultura em 1982 e regravado no álbum "A música brasileira por seus compositores e intérpretes", selo SESC, 2000. As entrevistas de Toniquinho Batuqueiro e Carlão do Peruche foram realizadas por Oliveira Santos e publicadas em sua dissertação de mestrado (2015). A entrevista de Tio Mário, que trabalhou como "chapa" no Largo da Banana e foi sambista da escola Camisa Verde e Branco, foi realizada por Filipe Amado em 2017 e gentilmente cedida por este à autora.

41. Gomes da Silva, op. cit. p. 53 .

42. Gomes da Silva, op. cit., p. 56 .

43. Entrevista de Tio Mário a Filipe Amado, 2017 (documento audiovisual). 
44.. Id.

45. Apud Oliveira Santos, op.cit., p. 137.

46. Depoimento do jornalista Oswaldo Faustino à Prof. Dra. Ana Cláudia Castilho Barone (set. 2018).

47. Moraes (1978, p. 34).

48. Sobre as aproximações entre a tiririca e a capoeira, cf. Amado (2019).

49. Oliveira Santos, op. cit. p. 13.

50. Oliveira Santos (2013, p. 4).

51. Apud Oliveira Santos, op.cit., p. 173. assistido a esse jogo em outras partes da cidade, como na rua Direita, onde presenciou a interrupção de uma roda pela polícia, e também na cidade de Santos. ${ }^{44}$

A prática da tiririca estava associada ao samba. Baseando-se principalmente em depoimentos orais, Oliveira Santos explica sua organização:

A dança acontecia em roda. Formando o círculo ficavam os batuqueiros, entoando refrãos em coro, enquanto no centro um par de indivíduos dançavam o samba, fazendo as chamadas "visagens", ameaças de ataques para testar a reação do adversário [...] neste jogo da tiririca os dois participantes dançam e desferem rasteiras ao mesmo tempo, no que reside sua característica peculiar. $\bigcirc$ objetivo da brincadeira era levar o oponente ao chão. Assim, quando visualizava a possibilidade de desferir uma rasteira, o jogador a aplicava repentinamente, na maior velocidade possível, para não sofrer risco de ser acertado por um contragolpe do companheiro. Ao ser derrubado, o perdedor dava lugar a um novo desafiante. ${ }^{45}$

Existem outras versões sobre o funcionamento daquela prática. Em depoimento, o jornalista Oswaldo Faustino descreve uma dinâmica de jogo em que uma única pessoa, situada no centro da roda, tentava derrubar os demais participantes, em sequência. ${ }^{46}$ Quem caísse deveria pagar uma quantia em dinheiro. Wilson Rodrigues de Moraes registrou uma demonstração de tiririca por dois passistas da Escola de samba Camisa Verde e Branco, ${ }^{47}$ atestando a realização dessa prática na Barra Funda, bem como indicando formas de aproximação entre a tiririca e o samba. Ela também é associada ao universo da capoeira, por consistir em uma disputa entre dois adversários no centro de uma roda, pela existência de golpes comuns às duas práticas, como a rasteira e a banda, pela marcação rítmica através de instrumentos musicais, entre outras. ${ }^{48}$ Houve em São Paulo sambistas reconhecidos por suas habilidades na capoeira e na tiririca, a exemplo do apitador Pato n'Água, homenageado por Geraldo Filme na canção "Silêncio no Bexiga" (1968). A tiririca podia ser encontrada até meados do século XX em praças e largos da cidade de São Paulo onde se desenvolviam núcleos informais de música, ${ }^{49}$ tais como o Largo da Banana, as Praça da Sé, da República e João Mendes e o Largo do Correio. Sua presença era característica em espaços de reunião de trabalhadores de rua, como engraxates, vendedores, carregadores, entre outros. Por isso, ela era localizada sobretudo nas áreas mais centrais, embora Oliveira Santos tenha identificado registros da prática em em regiões mais afastadas, como no Largo do Peixe, na Vila Matilde..$^{50}$ A própria Barra Funda constituía, nas primeiras décadas do século XX, um "arrabalde" da cidade. À condição "isolada" do bairro o sambista Toniquinho Batuqueiro associava a presença mais frequente de demonstrações de valentia: "Barra Funda... era mais sozinha. Era mais negócio de valentia, valentia... pau de barulhento, que fazia barulho, briga que é bom não tinha $[\ldots .]^{\prime \prime} .{ }^{51}$ Assim, o sambista sugere que 
mostrar-se "valentão" era parte da brincadeira, mais do que uma ameaça propriamente dita. Com isso, insistiu no caráter lúdico daquela prática.

Nos álbuns gravados com Plínio Marcos, Geraldo Filme canta uma cantiga que poderia ter sido aprendida nas próprias rodas de tiririca. ${ }^{52} \mathrm{Em}$ "Balbina de lansã" (1971) ela foi apresentada sob o nome de "Tumba, moleque tumba". A mudança do título para "Tiririca" na versão de 1974 pode estar relacionada com o propósito do álbum de contar a história do samba de São Paulo, uma vez que os artistas defendiam que a tiririca era um dos elementos constitutivos da especificidade do samba paulista.

Tiririca (1971 e 1974)

É tumba, moleque, tumba Tumba pra derrubar

Tiririca, faca de ponta

Capoeira quer te pegar

Dona Rita do Tabuleiro Quem derrubou meu companheiro?

Abre a roda, minha gente, Que o batuque é diferente!
52. Outra possibilidade é que Geraldo Filme tenha conhecido a cantiga durante sua experiência junto ao Teatro Popular Brasileiro, dirigido por Solano Trindade na cidade de Embu a partir de 1961. Aquele grupo reuiniu diversos artistas populares negros, entre os quais o Mestre Ananias (1924-2016), capoeirista nascido em São Felix, cidade do Recôncavo Baiano e radicado em São Paulo desde 1953. Marchezin, op. cit., p.27. Em 2011, Mestre Ananias gravou a cantiga em um de seus álbuns.

53. Marchezin observa que a tematização e reconstrução do jogo da tiririca para o ouvinte estrutura-se a partir da relação entre letra e melodia. Marchezin, op.cit., p.102.

54. Siqueira (2017, p.6).

55. Marchezin, op.cit., p.103.

A canção recria um jogo de tiririca e o ambiente em que ele se passa. ${ }^{53}$ Narrando uma disputa entre dois jogadores, o samba remete à lógica interna da sociabilidade da tiririca e da capoeira. A primeira estrofe presta-se à construção de um clima de suspense, anunciando o desafio entre dois oponentes. A repetição da palavra "Tumba" alude ao elemento percussivo que marca o tempo e orienta a roda. Essa batida contribui para criar a ambientação do jogo, produzindo a tensão diante da queda eminente ("tumba pra derrubar", "capoeira quer te pegar"). A presença da "faca de ponta" indica que, além do elemento lúdico, há uma situação de conflito. $\bigcirc$ uso de navalhas e facas dentro e fora do jogo era recorrente nas primeiras décadas do século XX, como atesta o alto número de incidentes registrados nas delegacias de polícia da cidade. ${ }^{54}$ Segundo Marchezin, as rimas de "derrubar" e "pegar" coincidem com os tonemas que levam ao efeito de suspensão, intensificando a ideia de perigo sugerida pela letra. ${ }^{55}$

Não há consenso acerca do significado de "tumba" na canção. Para Marchezin, trata-se de uma modalidade de rasteira ou uma referência à palavra "tombo" ("ato ou efeito de tombar, queda") e à ação de "tombar" ("derrubar, 
56. Ibid., p.102.

57. Azevedo, op.cit., p.138.

58. Oliveira Santos, op.cit., p.142.

59. Marquezin (2016, p.107)

60. A identificação entre "Dona Rita do Tabuleiro" e o ambiente em que se passa o jogo também é sugerida por Marchezin, op. cit., p.104.

61. Oliveira Santos, op. cit., p.180.

62. Marchezin, op. cit., p.107. fazer cair ou cair"). ${ }^{56}$ Para Azevedo, a palavra é um sinônimo para "briga". ${ }^{57}$ Outro sentido possível, sugerido por Oliveira Santos, é o de "pedra sepulcral". 58 Nesse caso, reforça-se a ideia de que a brincadeira tornou-se "perigo de morte". A palavra "moleque" sugere a inexperiência de um dos jogadores, o que aumenta sua exposição ao perigo. Todavia, a vivência de uma situação conflituosa e perigosa não corresponde, necessariamente, a algo negativo. Pelo contrário, pode ser uma forma de exaltar a coragem dos adversários. Além disso, ao advertir o moleque sobre os perigos do jogo, o eu lírico, que atua como observador e participante, ${ }^{59}$ remete à transmissão oral de saberes, característica das tradições africanas. Essa forma de aprendizado aproxima-se da própria experiência de Geraldo Filme no Largo da Banana, em sua relação com os "coroas" a cujo trabalho ele e outros moleques deram continuidade. Na segunda parte da cantiga, um dos oponentes vai ao chão, cumprindo-se assim o objetivo do jogo. Entende-se que foi aplicada uma rasteira muito rápida, uma vez que o observador parece não ter visto a queda, perguntando à Dona Rita do Tabuleiro como o fato aconteceu. A figura da vendedora também ajuda a qualificar o lugar em que acontecia a roda: era um espaço público, onde quituteiras vendiam suas iguarias. A referência a uma prática associada, principalmente, a mulheres negras, a presença de Dona Rita do Tabuleiro contribui para criar a ambientação de um território afro-brasileiro onde se desenvolve a cena narrada. ${ }^{60}$

Na última parte, após a queda de um dos participantes, o jogo se transforma em confusão, a ponto de ser necessário "abrir a roda". Há indícios de que situações em que a brincadeira desandava em desavenças mais sérias eram relativamente frequentes. Toniquinho Batuqueiro canta: "Abre a roda, meninada/ Que o samba virou batucada/ que o samba virou batucada/ que o samba virou...", explicando que a batucada refere-se ao "samba duro", samba de "valente pra não deixar dúvida [...] Se a polícia chegasse o que tava na pior agradecia $[\ldots]^{\prime \prime}{ }^{61}$ Assim, a ação de abrir a roda pode também estar associada à chegada da polícia.

Do ponto de vista musical, Marchezin associa o funcionamento rítmico da canção à prática da tiririca. Tendo em vista que o objetivo era derrubar o oponente aplicando rasteiras, o momento mais apropriado para aplicar o golpe seria aquele em que o adversário estivesse transferindo o peso do corpo de um pé para o outro, quando sua base era menos firme. A acentuação dada por Geraldo Filme condiz justamente com tais momentos, fora dos tempos principais do compasso e da sua principal subdivisão, o contratempo. Isso confere à música o balanço característico da dança, assim como assinala o momento ideal para aplicar o golpe. ${ }^{62}$ 
Toniquinho Batuqueiro conta que Geraldo Filme não era bom de pernada, mas apesar disso era respeitado por ser bom cantador. ${ }^{63}$ Geraldo Filme falou sobre sua vivência nessas rodas. Seu relato permite qualificar a tiririca como uma prática atrelada ao samba, reprimida pela polícia, e feita com instrumentos improvisados:

[...] a tiririca é o jogo da pernada né. Aí, naquela brincadeira, na época não podia fazer samba na rua em São Paulo [...] fazia samba e ia em cana. A gente já saía [...] [com] uma moeda de dois mil-reis [...] no bolso porque sabia que quem cantava samba ia preso [...] Como não tinha instrumento, a palma da mão, uma lata de lixo, caixa de engraxate, tudo que desse som servia. Ah, aí a gente armava a roda [...] e ficava brincando de pernada lá até os homem [sic] chegar entende? Aí quando os homem [sic] chegava acabava a roda. ${ }^{64}$

As diferentes posturas dentro da roda também revelam a heterogeneidade entre os praticantes, que tinham vivências diferentes dentro do universo do samba ou da própria tiririca. Geraldo Filme talvez não estivesse entre os maiores valentões bons de briga, mas transitava entre eles e compartilhava vivências. "Baiano capoeira", composta em parceria com Jorge Costa e gravada em 1962 por Germano Mathias, contribui para aprofundar a reflexão acerca do modo como as noções de coragem e valentia operavam. Na canção, que trata de um acerto de contas, remete-se à capoeira, outra prática afro-brasileira, que é retratada como parte do cotidiano, diretamente ligada às estratégias de sobrevivência na cidade.
63. Oliveira Santos, op. cit., p.184.

64. Souza, op. cit. (Documento audiovisual).

\section{Baiano capoeira (1962)}

Tem que ser agora

Vamos resolver aquele velho assunto

Não sou tatu para morrer cavando Nem perna de porco pra virar presunto

(Vou te fazer defunto)

Vamos no esquisito Resolver esta parada pra ver como é Tu és malandro brigas bem no aço

Sou baiano capoeira e brigo bem no pé

(Só prá ver como é)

Vamos procurar um território diferente

Pra resolver esta situação

Não ponhas banca aqui no meu distrito

Pra "mim" não invadir tua jurisdição 
65. Cabral (2002, p.138).

66. Sobre relações entre valentia e malandragem em

São Paulo, não necessaria-

mente relacionadas com o samba, cf. Ciscati (2001).
Não acredito em homem valente Pois o meu nome ainda não morreu

Cante de galo lá no teu terreiro

Porque aqui no morro quem canta sou eu (Vacilou, morreu !)

Na primeira estrofe, há uma convocação para a resolução de um conflito, em uma briga. Na segunda, são apresentadas as personagens envolvidas no incidente: alguém que briga bem no aço, ou seja, porta uma navalha ou uma faca, e um baiano capoeira, que como tal, tem habilidade com os pés. É a destreza do capoeirista que vai garantir sua sobrevivência em um ambiente hostil e perigoso. Trata-se da aplicação do conhecimento da capoeira nas situações enfrentadas no cotidiano, fora do seu ritual tradicional e lúdico.

Alguns recursos, como o emprego de gírias, contribuem para retratar o ambiente urbano em que se desenvolvia aquela disputa. A divisão da cidade em territórios distintos, marcados por rivalidades, aparece nas duas últimas estrofes. Para que a disputa seja justa, é necessário buscar uma área neutra. Para demarcar esses espaços, são empregados os termos "um território diferente" (neutro), "meu distrito" e "aqui no morro" (área do capoeira), "tua jurisdição", "teu terreiro" (espaço do outro). $\bigcirc$ vínculo dos espaços dos duelantes ao "terreiro" e ao "morro" simbolizando o local de moradia da população negra e pobre, a partir da referência do Rio de Janeiro - reforça a constituição de territorialidades negras. A elas se associam a prática da capoeira e as normas de condutas mobilizadas ao longo da canção. Muniz Sodré refere-se à "pluralidade de afetos" - amor, ódio, desejo - como elementos constitutivos da territorialização. $\bigcirc$ autor observa que:

Por ser instauradora de ordenamentos sociais, essa sociabilidade festiva comportava aspectos violentos, tipificados nos sangrentos encontros entre grupos rivais [de festejos carnavalescos]. A violência (que existia, aliás, desde a época do entrudo carnavalesco) fazia-se também presente nos grupos conhecidos como "malandros" e "capoeiras" ou "desordeiros", que desfilavam nos dias de carnaval. ${ }^{65}$

A valentia, a força e o recurso à violência eram elementos que contribuíam para atribuir "fama" ao sujeito, algo explorado na última estrofe da canção: quanto mais destemido e perigoso, melhor. ${ }^{66}$ Quando o capoeira diz "não acredito em homem valente/ pois o meu nome ainda não morreu", está demonstrando sua coragem e sua fama, conquistadas em sua trajetória de brigas. 
Ele está confiante de que não vai perder a disputa para a qual está desafiando o oponente, expulsando o rival de sua "área", ao fim da canção, reafirmando seu poder sobre aquele território. Em São Paulo, grupos de "valentes" foram associados a determinados espaços da cidade, em que se realizavam práticas de trabalho informal e de samba e tiririca. Na Barra Funda, nos anos 1920, os "negros da Glette" foram lembrados por antigos sambistas do bairro. Britto afirma que os "negros da Glette", também denominados de "bambas da Barra Funda" por sua habilidade no samba, eram carregadores do Largo da Banana. ${ }^{67}$ Conforme depoimento de Dionísio Barbosa, os negros da Glette não tinham livre acesso a outros espaços negros do bairro, como os salões de baile. No entanto, eles costumavam fazer a segurança desses eventos. Assim, eles eram, ao mesmo tempo, excluídos de determinadas formas de sociabilidade negra e necessários para sua viabilização. ${ }^{68}$ Dona Sinhá conta que eles também costumavam abrir os desfiles dos cordões carnavalescos, protegendo os estandartes contra as agremiações concorrentes. ${ }^{69}$ Esses relatos também chamam a atenção para a necessidade de reconhecer a heterogeneidade entre grupos sociais negros, mesmo entre aqueles identificados com o samba. Tal heterogeneidade resultava em diferentes formas de inserção social e diferentes modos de acessar a cidade.

Geraldo Filme menciona outro importante espaço de sociabilidade negra da Barra Funda, o clube de futebol São Geraldo, nas imediações do Largo da Banana. Esse clube, que existiu entre 1917 e meados dos anos 1940, contando unicamente com integrantes negros, se notabilizou como um dos melhores times da cidade, alcançando diversos títulos, entre os quais o de campeão da Copa do Centenário, em 1922.70

Na própria Avenida Pacaembu [...] tinha o campo de São Geraldo ali [...] um clube de futebol que jogava um pessoal exatamente que trabalhava carregando saco, descarregando banana, fardo de algodão, aquela raça toda. E eles brigavam muito. Então o chefe de polícia... resolveu ser presidente do clube pra poder maneirar a coisa [...].71

É significativa a formação de um time constituído unicamente por integrantes negros, em um momento em que a maior parte das agremiações esportivas restringiam o acesso a essa população. A caracterização feita pelo sambista indica que aquela sociabilidade era mediada por relações sociais complexas, exemplificada pela presença do chefe de polícia no time. A complexidade dessas figuras também se revela na canção "Mulher de Malandro", gravada em 1980.
67. Britto, op.cit., p.91.

68. Entrevista de Dionísio Barbosa a José Ramos Tinhorão, 1976, em projeto do MIS-SP (Documento audiovisual).

69. Apud. Prado (2013, p. 53).

70. Domingues (2015 p.369-71).

71. Souza, op. cit. (documento audiovisual). 


\section{Mulher de Malandro}

Meu bem, eu vou-me embora não fique triste, mulher de malandro não chora $(2 x)$

Eu fiz de tudo para ser bom operário veio a crise financeir, a eu perdi o meu trabalho

Vou com o Sol volto com a luz da Lua Oh, meu bem, não fique triste, dinheiro se ganha na rua

Meu bem, eu vou-me embora não fique triste, mulher de malandro não chora $(2 x)$

Dê um beijo nos negrinhos, vou ganhar o nosso pão Carregar algumas malas lá na porta da estação Engraxar sapato e bota, carregar cesto na feira Alugar uma casaca, ser garçom de gafieira

Meu bem, eu vou-me embora não fique triste, mulher de malandro não chora $(2 x)$

Hoje vou jogar no bicho, minha jura quebrarei quero ver se aumento um pouco sobre aquele que eu ganhei Oh, meu bem, não tenha medo, pois o jogo não dá nada para tudo, dá-se um jeito, a polícia é camarada.

Meu bem, eu vou-me embora não fique triste, mulher de malandro não chora $(2 x)$

Vou vender bala de coco, barbatana e rapadura Oh, meu bem, só tenho medo do fiscal da prefeitura pra arrumar algum dinheiro, garantir nossa gordura vou em algum velório de rico, vou chorar na sepultura.

Um "malandro" despede-se da esposa, partindo em busca de dinheiro. Trata-se de um casal pobre e negro, com filhos "negrinhos". Diferentemente do estereótipo do malandro "vadio", o da canção está preocupado com o sustento da família. Na primeira estrofe, ele é retratado com um "bom operário" que, no entanto, se vê desempregado e deve buscar alternativas. Tal ideia não se coaduna com a figura de alguém que busca transgredir as normas sociais, ao menos como um fim em si próprio. Diante disso, é na rua que se encontram as oportunidades. É construído um movimento de informalidade crescente das ocupações perseguidas pelo sujeito. Atividades mencionadas pelo eu lírico, como carregar malas na porta da estação de trem, trabalhar como engraxate, trabalhar na feira, poderiam ser realizadas no Largo da Banana e seu entorno. 
A condição de "malandro" traz ao eu lírico vantagens e desvantagens. Por um lado, ele é versátil, capaz de realizar múltiplas tarefas. Agindo ambiguamente frente às normas sociais, ele transita entre o legal e o ilegal para melhorar seus rendimentos. Suas práticas são mantidas no campo da informalidade, sendo ora aceitas, ora reprimidas. Seu relacionamento com as autoridades evidencia essa ambiguidade. Na penúltima estrofe, o malandro pretende jogar no bicho, atividade considerada ilegal, mas não há problema, pois a polícia "é camarada". Já na última, ele se propõe a trabalhar no comércio ambulante, mas neste caso, teme "o fiscal da prefeitura". A última atividade mencionada pelo malandro, "chorar em sepultura de rico", indica uma relação irônica com as classes mais abastadas. Percebe-se que a figura do "malandro" muda de significado conforme a situação e se relaciona com outras construções complexas, como as "autoridades" mencionadas na canção. ${ }^{72}$

samba-enredo "Tebas, o escravo" (1974), composto para a escola de samba Paulistano da Glória, homenageia a Praça da Sé, contando a história de Tebas, negro escravizado responsável pela construção da torre da Catedral da Sé durante o século XVIII, feito através do qual negociou sua liberdade. Com essa homenagem, o sambista valorizava a memória de um herói negro esquecido, cujo nome não constava entre os homenageados nos painéis comemorativos do aniversário de São Paulo, supostamente destinados a apresentar o nome "dos autores, construtores todos..." .73

Tebas, o Escravo (1974)

Tebas, negro escravo Profissão alvenaria

Construiu a velha Sé

Em troca pela carta de alforria Trinta mil ducados que the deu padre Justino

Tornou teu sonho realidade

Daí surgiu a velha Sé

Que hoje é o marco zero da cidade

Exalto no cantar de minha gente A sua lenda, seu passado, seu presente

Praça que nasceu do ideal E braço escravo, é praça do povo Velho relógio, encontro dos namorados Me lembro ainda do bondinho de tostão

Engraxate batendo a lata de graxa

E o camelô fazendo pregão

tira-teima dos sambistas do passado
72. Para uma análise sobre a complexidade em torno da construção do estereótipo do "malandro" e como ele foi mobilizado no contexto do samba no Rio de Janeiro, Cf. Hertzman (2013).

73. Souza, op. cit (documento audiovisual). O papel histórico de Tebas tem sido objeto de reconhecimento recente. Em 2018, um livro sobre o arquiteto negro foi publicado pelo Instituto para o Desenho Avançado (IDEA), em parceria de fomento referente ao edital de chamamento público $n^{\circ} 001 / 2018$, processo administrativo $\mathrm{n}^{\circ}$ 017/2018, do Conselho de Arquitetura e Urbanismo de São Paulo (CAU/SP). No mesmo ano ele foi reconhecido como arquiteto pelo Sindicato dos Arquitetos do Estado de São Paulo. Cf. Ferreira (2018). 
74. Britto, op. cit., p.101.

75. Azevedo (2006, p. 113) observou que a ligação entre tempos históricos e experiências sociais distintas é uma marca das músicas com temática histórica de Geraldo Filme. O compositor assim procede neste samba-enredo, ao remeter primeiro ao tempo em que Tebas construiu a torre da catedral e depois ao tempo em que Geraldo Filme jogava tiririca na Praça da Sé. Para o pesquisador, isso parece sugerir uma continuidade entre a história dos afro-descendentes de um tempo remoto e daqueles do presente. Nesse sentido, a comparação entre Tebas e os sambistas do Largo da Banana não escapa à lógica criativa do compositor cuja obra é aqui analisada.

76. A expressão "nego pinga" é empregada por Britto $(1986$, p. 39$)$
Bexiga, Barra Funda e Lavapés

O jogo da tiririca era formado

O ruim caía e o bom ficava de pé

No meu São Paulo, oilelê, era moda

Vamos na Sé, que hoje tem samba de roda

Na primeira parte da canção, são destacadas as habilidades de Tebas como construtor, sua importância para a existência da "velha Sé" e sua astúcia em negociar a liberdade graças às suas qualidades. Com isso, restituía-se ao marco zero da cidade sua origem negra e popular. Isso é reforçado na passagem para a segunda parte da música: "Praça que nasceu do ideal/ E braço escravo, é praça do povo". Essa perspectiva, que dá reconhecimento e valor à contribuição social do negro, contrasta com a visão convencionada sobre os trabalhadores braçais, como aqueles do Largo da Banana. Esses homens foram caracterizados como indivíduos de baixa escolaridade, brutos, operando unicamente com o emprego da força física. ${ }^{74}$ Tebas, sendo escravo e construtor, representa o trabalhador braçal. No entanto, não é um ignorante, mas um construtor audacioso, hábil, detentor de um saber único, visto que apenas ele teve condições de erigir a torre da catedral. O ideal de liberdade que fundamenta a existência da Praça da Sé também pode ser lido como metáfora para a insubordinação diante da opressão sofrida. A resistência não se revela unicamente mediante o emprego da força física, mas também através do intelecto e das tradições dos descendentes dos povos africanos. A canção destaca práticas sociais ligadas ao samba, como o samba dos engraxates, o tira-teima dos sambistas, a tiririca e o comércio ambulante.

O movimento de resgate da memória e de valorização do negro, através da celebração das qualidades de Tebas, nos permite indagar sobre as características dos trabalhadores do Largo da Banana. ${ }^{75}$ Por um lado, a habilidade na briga, em geral retratada por terceiros de forma pejorativa, facilitava-thes a sobrevivência em uma sociedade em que não thes era concedida uma cidadania plena. Ademais, esses homens eram mestres, detentores de saberes únicos, e deles Geraldo Filme recebeu importantes ensinamentos acerca do universo do samba. Se fossem apenas "negros pinga" bons de briga, poderiam eles ser os transmissores de uma tradição cultural à qual Geraldo Filme tanto se orgulhava de dar continuidade?76 A perspectiva sugerida pelo sambista contribuiu para caracterizar de forma mais rica e plural um grupo social cuja memória é escassa e sujeita a inúmeras distorções, bem como para melhor conhecer seus espaços na cidade. 
Em diversas canções, Geraldo Filme reporta-se a espaços relacionados com a sociabilidade do samba e refere-se às transformações urbanas que incidiam sobre as vivências dos negros e sambistas na cidade. Uma de suas canções mais conhecidas é "Tradição" (1975), em homenagem à Escola de Samba Vai-Vai. Nela, que se tornou um hino da escola, o sambista reforça a estreiteza do vínculo entre a agremiação e o bairro em que ela se localiza, o Bixiga.

\section{Tradição}

Quem nunca viu o samba amanhecer

Vai no Bixiga pra ver $(2 x)$

O samba não levanta mais poeira Asfalto hoje cobriu o nosso chão Lembranças eu tenho da Saracura Saudades tenho do nosso cordão

Bixiga hoje é só aranha-céu E não se vê mais a luz da lua Mas o Vai-Vai Está firme no pedaço É tradição e o samba continua

Ao mesmo tempo em que celebra a presença da Vai-Vai e do samba no Bixiga, a canção é carregada de nostalgia, opondo o presente e o passado do bairro. $\bigcirc$ passado é caracterizado pelo chão de terra, que levantava poeira na várzea da Saracura, iluminada pela luz da lua. Além disso, o eu lírico rememora o cordão carnavalesco do Vai-Vai, fundado ainda na década de 1920 e que em 1972 havia sido convertido em escola de samba. $\bigcirc$ presente é representado pelo asfalto, que eliminou a poeira do chão, e pelo arranha-céu, que cobre a luz da lua. Entretanto, o samba resiste a essas transformações, permanecendo como uma tradição do bairro. Ao mesmo tempo em que há, de fato, nostalgia com relação ao passado, não é possivvel afirmar que haja um completo antagonismo entre a perpetuação da tradição do samba e o processo de urbanização. Entretanto, a continuidade do samba resulta de um esforço consciente da comunidade sambista. Geraldo Filme participou da VaiVai na década de 1970, tornando-se diretor da escola em 1981.77 Comentando seu envolvimento com o bairro e com o samba naquele momento, o sambista afirmou: 
78. Souza (1981) (documento audiovisual). Embora o sambista mobilize a noção de "território livre", assim como Britto, o significado da expressão para cada um dos autores diverge em pontos importantes. Mesmo que ambos associem tal ideia à festa e ao samba da população negra, o discurso do sambista enfatiza a liberdade dentro do próprio território - um não cuida da vida do outro. A pesquisadora, por sua vez, faz uma correspondência entre a formação do território livre e a negação do restante da cidade por seus ocupantes.

79. Apud Marchezin, op. cit., p.85.

80. Nascimento (2015, p. 87-88).

81. Souza, op. cit. (documento audiovisual)

82. Ibid.
[...] estou vendo necessidade de erguer a Vai-Vai, pois gosto daquele povo, daquela raiz, pena que ali é centro da cidade e aquela gente mudou, acabaram os cortiços. Antigamente, eu entrava no Bexiga numa sexta e saía de lá no domingo, na segunda de manhã. Era festa, era música, come na casa de fulano, dorme aqui, dorme ali, era um território livre aquilo, um não cuidava da vida do outro, um bairro alegre. Eles tão tentando hoje reerguer essa tradição, tão promovendo festas e aí eu sentia necessidade de ir pra lá, que eu considero assim um dos últimos redutos negros [...] Eu fui pro Bexiga e me dei bem no meio daquela negrada toda!?8

Em sua fala, o cantor explicitou, portanto, a realização de um esforço coletivo para "reerguer" a tradição do samba no Bixiga. Outra questão importante assinalada nesta passagem é a relação entre a realização do samba e a presença dos cortiços no bairro, bem como uma oposição entre "centro" e "samba". A sociabilidade nos cortiços e nos porões também é relembrada por outros sambistas da escola, como seu Chiclé, para quem o bairro, antigamente, era "dominado pelos cortiços". Segundo ele, isso era "maravilhoso, você saía de uma festa aqui, tinha outra festa lá. Se não tinha, todo mundo se juntava e fazia uma festa só. Tinha festa no porão, que a maior parte era festa no porão"..$^{79}$ Larissa Nascimento observou que, na década de 1960, um conjunto de intervenções viárias, tais como a construção da Radial Leste-Oeste, da Avenida 23 de Maio, do Elevado Costa e Silva e do Viaduto do Café resultaram na demolição de inúmeros cortiços e na expulsão de um grande número de moradores daquele bairro, que se deslocaram para outras regiões como Casa Verde, Cidade Tiradentes e Grajaú. ${ }^{80}$ As sociabilidades e redes de relações dos sambistas, e da população negra e pobre em geral, não foram levadas em consideração no processo de implantação dos projetos de urbanização. Desta forma, não apenas a possibilidade de manutenção das festas foi afetada, mas também inúmeras famílias foram desalojadas e tiveram de se mudar para áreas mais periféricas. Assim sendo, pouco puderam elas se beneficiar de eventuais melhorias advindas desse processo.

Ao referir-se à Barra Funda, Geraldo Filme também opôs sua ocupação por uma população pobre e negra àquela do centro da cidade: "a Barra Funda era um bairro, assim, próximo do centro, mas ela tinha uma característica bem de bairro, assim, de periferia, sabe [...] então, aquelas [sic] casas mais humildes, moravam os negros". ${ }^{81}$ Na visão do músico, era essa a condição que garantia a existência do samba no bairro. No entanto, diferente do Bixiga, para Geraldo Filme a Barra Funda deixara de ser um reduto negro, permanecendo ali apenas a escola de samba Camisa Verde como um espaço negro, mas não o bairro como um todo. ${ }^{82}$

Entre os anos 1940 e 1960, São Paulo apresentou um intenso crescimento populacional, em muito devido ao fluxo migratório de outros estados. Isso foi acompanhado de um processo de expansão da cidade, para o qual a travessia dos 
trilhos das ferrovias era uma parte fundamental. Nesse período, a municipalidade empreendeu a construção de um conjunto de intervenções viárias, muitas das quais haviam sido idealizadas muito antes, ainda nos anos 1920.83 Nos anos 1950, às antigas propostas do Plano de Avenidas se articulariam concepções do Programa de Melhoramentos Públicos de São Paulo, coordenado por Robert Moses, notadamente um sistema de vias expressas, reforçando a estruturação metropolitana a partir do sistema viário e do privilégio do transporte individual. ${ }^{84} \bigcirc$ Viaduto Pacaembu encontrava-se entre as obras executadas naquele momento. Após sua idealização na década de 1920,85 a construção do viaduto voltou a ser gestada pelo poder público em 1945.86 Entretanto, sua execução tardaria mais de uma década. Em 1955, promulgou-se uma lei autorizando a emissão de crédito para a construção de 11 viadutos sobre as ferrovias da cidade. ${ }^{87}$ Desses, quatro foram inaugurados durante a prefeitura de Adhemar de Barros (1957-1961): os viadutos Pacaembu (1958), Rio Branco (1959), Lapa (1960) e Domingos de Moraes (1960). $\bigcirc$ Viaduto Pacaembu estendia-se do Largo da Banana à Rua do Bosque, do outro lado dos trilhos.

Em suas canções "Vou Sambar n'outro lugar" e "Último Sambista", Geraldo Filme já apresentava sua visão de que as transformações da Barra Funda haviam eliminado o antigo reduto negro, algo que ele reiterou ao justificar sua ida para a Vai-Vai nos anos 1970. Assim, a forma de resistência do samba sugerida por essas canções, diferentemente do que apresentou em "Tradição", era a despedida do artista, em busca de outros espaços para sambar. Nas duas canções que homenageiam o Largo da Banana, a partida do sambista não é caracterizada como expulsão, mas como autodeterminação. Em "Vou sambar n'outro lugar", com que abrimos este artigo, não há que se falar em fim do samba, mas sim em "ir sambar em outro lugar". Da mesma forma, em "Último Sambista", gravada pelos Demônios da Garoa em 1968, o artista se despede, com saudade, da Barra Funda e do Largo da Banana, mas não do samba, pois vai embora com o cavaquinho nas mãos:
Último Sambista

Adeus,

Tá chegando a hora

Acabou o samba,

Adeus, Barra Funda

Eu vou-me embora

(Adeus)

Veio o progresso

Fez do bairro uma cidade

Levou a nossa alegria

Também a simplicidade
83. Muitas dessas intervenções foram incorporadas ao Plano de Avenidas de Prestes Maia e Ulhôa Cintra, idealizado na década de 1920 e publicado em 1930 . Entretanto, sua implementação foi lenta e descontínua, iniciando-se na administração do próprio Prestes Maia, a partir de 1938. Como observou Silva (2018, p. 2), a instabilidade política e descontinuidade administrativa foi um dos fatores que provocaram um descompasso no desenvolvimento daquele e de outros planos urbanísticos e trabalhos técnicos no período. A primeira referência à necessidade de construção de um viaduto sobre a antiga estação da Barra Funda que identificamos encontra-se em um debate da Câmara Municipal de 1914.

84. Silva, op. cit., p.4.

85. Lei municipal $n^{\circ} 2.877$ de 18 de junho de 1925 .

86. Em 1945 foi publicado o Decreto $n^{\circ} 647$, que declarava de utilidade pública as áreas necessárias ao prolongamento da Avenida Pacaembu até a Ponte da Casa Verde, sobre o Rio Tietê.

87. Prefeitura Municipal de São Paulo (1955). 
Deixo este samba Que eu fiz com muito carinho Levo no peito a saudade Nas mãos o meu cavaquinho (Adeus, Barra Funda!)

É interessante observar que alguns elementos se repetem nas três canções. Em "Tradição", "Vou Sambar n'outro lugar" e "Último Sambista", são estabelecidas formas de contraposição entre o passado, marcado por uma carga nostálgica, e pelo presente, associado ao processo de urbanização. Entre passado e presente, transita o amor pelo samba e o desejo de perpetuá-lo. Nas duas músicas que tematizam as transformações da Barra Funda, o compositor associou as intervenções que incidiam sobre o Largo da Banana à ideia de "progresso". Em "Último Sambista", o progresso fez do bairro uma cidade, levando embora a alegria e a simplicidade que remetem ao samba. Já em "Vou sambar n'outro lugar", o surgimento do viaduto corresponde ao progresso, ao que se segue "eu não posso protestar". Retomamos, aqui, a indagação proposta no início do artigo: teria a ideia de progresso algum sentido para além de uma oposição à possibilidade do samba?

Marcos Virgílio da Silva fez algumas ponderações sobre essa questão, tomando "Vou sambar n'outro lugar" como referência e indagando sobre o significado do verso "eu não posso protestar". $\bigcirc$ autor rejeita a ideia de que tal verso refletisse a posição de que o sambista não tivesse razões para protestar, diante da queixa quanto à perda do terreiro, no início da canção, e da própria decisão de partir, com que a encerra. Dessa forma, o autor sugere que o "progresso" tem uma carga negativa, ou melhor, que há um preço muito alto a se pagar pelas suas vantagens. ${ }^{88}$ Todavia, tendo em vista que a caracterização do samba como expressão cultural negra, a valorização do negro e de suas produções, bem como as denúncias contra o racismo atravessam a produção de Geraldo Filme, acreditamos que essas canções sugerem algo um pouco diferente. Essas obras valorizam, ainda que de forma ambígua, o progresso, ao mesmo tempo em que se deseja a perpetuação do samba. Nesse sentido, a denúncia da perda dos espaços populares de samba constituía uma reivindicação para que as demandas dos sambistas fossem incluídas no projeto de modernização da cidade. Em um sentido mais amplo, isso representa um alerta para a necessidade de reconhecimento da população negra e pobre de São Paulo como agente social legítimo e dotada de direitos que deveriam ser contemplados na implementação do "progresso". 
Além de canções analisadas neste artigo, como "Tiririca" e "Tebas, o escravo", em que a valorização de saberes e práticas culturais negras são um tema central, Geraldo Filme tratou abertamente das desigualdades raciais em outras composições. Em "Batuque de Pirapora", o compositor narrou como após o menino ser recusado em uma procissão pelo fato de ser negro, sua mãe o leva para ser batizado no samba de Pirapora:

Batuque de Pirapora

Mamãe fez uma promessa

Para me vestir de anjo Me vestiu de azul-celeste

Na cabeça um arranjo

Ouviu-se a voz do festeiro

No meio da multidão

Menino preto não sai

Aqui nessa procissão

Mamãe, mulher decidida Ao santo pediu pediu perdão

Jogou minha asa fora

Me levou pro barracão

Lá no barraco

Tudo era alegria

Nego batia na zabumba

E o boi gemia

Em "Vai cuidar de sua vida", o compositor denunciou a apropriação de práticas culturais negras pelos brancos, ao mesmo tempo em que a população negra era perseguida:

\section{Vá cuidar de sua vida}

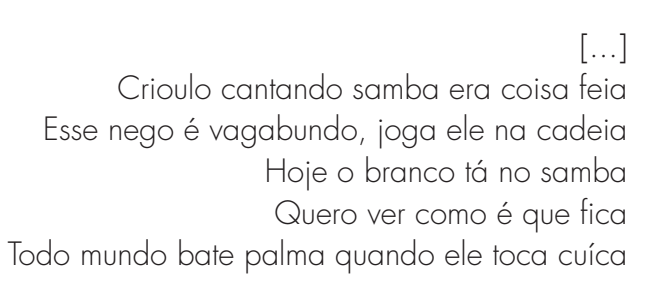

$[\ldots]$ 
Em "Tristeza do Sambista", Geraldo Filme denunciou as precárias condições de vida dos sambistas, negros e pobres, bem como a apropriação dessa cultura no âmbito do que ele denominava a "espetacularização" do carnaval. Assim, revela a angústia diante da falta de dinheiro, o temor de que o barraco desabe e mesmo seu alijamento do processo carnavalesco.

Tristeza do Sambista

Felicidade hoje é fantasia

E o povo canta mesmo sem saber

Que a favela virou poesia

Na boca de quem nunca soube o que é sofrer

Quando sopra o vento no mês de Fevereiro a nega me pergunta "o que fazer?"

O Zinco tremulando é um pesadelo só rezo e peço a Deus para nos proteger

Felicidade hoje é fantasia e o povo canta mesmo sem saber

que a favela virou poesia na boca de quem nunca soube o que é sofrer

Todos cantam todos falam mas esquecem o principal

a tristeza do sambista

é não ter no carnaval Sua própria fantasia e um barraco em condição para não ver a realidade no desfile da ilusão

Felicidade hoje é fantasia e o povo canta mesmo sem saber que a favela virou poesia na boca de quem nunca soube o que é sofrer

Embora existam outras obras do compositor que explorem essa temática, esses exemplos são suficientes para indicar sua posição crítica no que tange as relações raciais no Brasil, com uma denúncia explícita ao racismo e às condições de vida da população negra, marcadas pela pobreza, pela moradia precária, pela perseguição policial. Esse conjunto de preocupações, que se repete em tantas 
de suas canções, também está presente nas canções em homenagem ao samba do Largo da Banana e em sua crítica à intervenção urbana que acarretou seu "fim".

A construção do Viaduto Pacaembu sobre o Largo da Banana indica que o projeto de modernização urbana levado a cabo em São Paulo não acolheu a cultura do samba em seu programa nem tampouco incorporou as demandas da população negra e pobre, que teve seus espaços de lazer, trabalho e moradia demolidos pelas obras. Quase sempre, essa população foi expulsa para áreas cada vez mais periféricas e distantes. Ao mesmo tempo em que a eliminação dos lugares de samba engendrou formas de resistência, tais como a permanência "firme" do Vai-Vai no Bexiga ou a despedida da Barra Funda em busca de novos espaços de samba, isso não correspondeu a uma aversão ao "progresso". Ao contrário, havia, justamente, o desejo de que a população negra fosse incluída nas vantagens advindas daquele fenômeno. A crítica de Geraldo Filme incidia, portanto, sobre a correlação entre progresso/urbanização e eliminação de espaços de vida da população negra, mas não sobre o progresso ou a urbanização em si. Esse posicionamento, mesmo que pareça ambíguo, não é contraditório com um conjunto de ideias defendidas por militantes negros brasileiros no período de redemocratização (1 945-1964). Embora houvesse uma pluralidade de entendimentos acerca do que constituía o "problema do negro" na sociedade brasileira, "[d]e modo geral, todos advogavam que o Estado brasileiro deveria melhorar e universalizar a educação e a saúde públicas, assim como apoiar fortemente a valorização da cultura afro-brasileira". ${ }^{89}$ As reivindicações recaíam, portanto, sobre a universalização de direitos e de políticas públicas, de modo a incluir a população negra.

Assim, em "Último Sambista", se por um lado a chegada do progresso levava ao desaparecimento da "alegria" e da "simplicidade" que caracterizavam o samba, por outro a intervenção fazia com que aquele território sujeito, até então, a múltiplas formas de exclusão, fosse incorporado ao que era reconhecido como cidade. Já em "Vou sambar n'outro lugar", os versos "Sambista sem o Largo da Banana/ a Barra Funda vai parar" sugerem dois caminhos interpretativos distintos. Por um lado, é a Barra Funda marcada pela sociabilidade do samba que está desaparecendo, diante da perda do terreiro. Por outro, "a Barra Funda vai parar" pode também indicar que o sambista endossou o discurso sobre a necessidade da construção do viaduto sobre - Largo da Banana, diante do crescimento da cidade e da frota de automóveis. ${ }^{90}$ Essa ideia é reforçada pelos dois versos que se seguem: "Surgiu um viaduto, é progresso/ Eu não posso protestar". As canções permitem inferir dois movimentos diante do processo de urbanização. Um deles referia-se à reivindicação da inclusão das demandas específicas dos grupos negros no processo de modernização. Outro
89. Guimarães; Macedo (2008, p. 171)

90. Notícias de jornal publicadas naquele período indicam que a intensificação do trânsito era uma preocupação compartilhada por diversos grupos sociais que circulavam diariamente pela cidade. Siqueira (2017, p. 13). 
91. Ver entrevistas de Geraldo Filme e de Zezinho da Casa Verde ao MIS-SP, no início dos anos 1980. tratava da construção de uma imagem para a metrópole em desenvolvimento que incluísse e desse visibilidade às valiosas contribuições daquela população.

\section{CONSIDERAÇÕES FINAIS}

Neste artigo, tratamos de um antigo espaço de São Paulo que foi apontado por sambistas locais como um lugar significativo para a história da população negra da cidade. A partir da análise da obra de Geraldo Filme, assim como de alguns de seus depoimentos, tratamos de evidenciar as contribuições dos negros que frequentaram o Largo da Banana, focando em seus saberes e suas práticas. Buscou-se, assim, problematizar narrativas que enfatizaram a condição de marginalidade daquelas pessoas. Ao interpretar a agência dos sambistas negros e pobres do início do século sob essa chave, induziu-se o entendimento de que havia uma recusa daqueles sujeitos em participar na sociedade mais ampla. Com essa perspectiva, perde-se de vista a grande variedade de estratégias mobilizadas por aquele grupo social em sua luta por sobrevivência e por reconhecimento. Neste texto, buscamos contribuir para esse debate centrando-nos na percepção de Geraldo Filme sobre a ideia de "progresso" implicada em sua própria narrativa sobre o Largo da Banana como "berço" do samba paulistano. Ainda que a busca por espaços "escondidos", sobretudo da polícia, apareça na fala e na obra de diversos sambistas negros, ${ }^{91}$ a reivindicação nas vantagens advindas do progresso foi também uma demanda efetiva, muitas vezes pelos mesmos sujeitos.

Para Geraldo Filme, o desaparecimento do Largo da Banana se relacionou com o processo de desenvolvimento urbano na década de 1950. Este foi marcado pela execução de uma política rodoviarista gestada nas décadas anteriores. A construção do Viaduto Pacaembu foi marcada por uma ausência de debates quanto aos usos que se faziam do Largo da Banana ou às pessoas que o frequentavam. Contudo, no âmbito da vida cotidiana, aquele espaço havia abrigado uma sociabilidade rica e plural, que compreendia o trabalho nos armazéns e na estação, o comércio ambulante, o samba, jogos de tiririca, encontros em bares, festas e brigas. O reconhecimento da importância do Largo da Banana para a história da população negra da cidade foi posterior à construção do viaduto e esteve intrinsecamente ligado ao samba. Como as canções de Geraldo Filme sinalizam, a relação entre o fim do samba do Largo da Banana e a construção do viaduto tornou-se um elemento central dessas narrativas sobre a história cultural da cidade. Assim, a investigação da história daquele espaço lança luz tanto sobre o 
processo de apagamento da memória urbana negra no contexto da urbanização quanto sobre as lutas para a construção dessa memória.

As canções de Geraldo Filme revelam ambiguidades na forma como o processo de urbanização foi percebido. Elas apontam a incorporação dos discursos sobre progresso e modernidade então em voga, aos quais a imagem do viaduto foi associada. Nesse sentido, a denúncia da perda do espaço de samba estava imbuída da reivindicação por cidadania e inclusão na cidade moderna dos grupos negros e sambistas. Assim, a despeito de endossar a noção de "progresso", há também um posicionamento crítico do autor em relação à forma como foi conduzida aquela intervenção urbana. Os deslocamentos na busca por novos espaços de samba, a insistência em manter as festas apesar das transformações urbanas ou a reivindicação do direito a participar das vantagens prometidas em nome progresso representam algumas das estratégias pelas quais a população negra, pobre, trabalhadora, sambista respondeu às exclusões advindas do processo de urbanização, tal como foi conduzido. Nesse movimento, essas pessoas também ensinam a contar (ou a cantar) outras histórias sobre a cidade. 


\section{REFERÊNCIAS}

FONTES ICONOGRÁFICAS

LOCALIZAÇÃO do Largo da Banana, antes da construção do Viaduto Pacaembu, sobre mapa elaborado pelo consórcio Sara-Brasil em 1930. São Paulo, Geosampa, 2018.

FONTES IMPRESSAS

BARROS, Plínio Marcos de. "Carnaval”. Folha de S.Paulo, São Paulo, 12 fev. 1977, p.29.

BARROS, Plínio Marcos, et al. Balbina de Iansã - Trilha Sonora da peça teatral. São Paulo: Fermata, 1971.

BARROS, Plínio Marcos et al. Plinio Marcos em prosa e samba com Geraldo Filme, Zeca da Casa Verde e Toniquinho Batuqueiro. Rio de Janeiro: Warner, 1974.

CÂMARA MUNICIPAL DE SÃO PAULO. Processo $n^{\circ} 929$ de 1953 (Projeto de Lei $n^{\circ} 54$ de 1953). Autoriza o Executivo a despender a importância de Cr $\$ 96.000 .000,00$, destinada à construção de passagens de nível sobre o leito das Estradas de Ferro Sorocabana, Santos Jundiaí e Central do Brasil. São Paulo: Centro de Memória da CMSP, 1953.

CÂMARA MUNICIPAL DE SÃO PAULO. $7^{a}$ Sessão Ordinária de 14 de fevereiro de 1914. Atas e anais da CMSP. São Paulo: Centro de Memória da CMSP, 1914.

DIA dos Candidatos. Correio Paulistano, São Paulo, 17 mar. 1953.

DOIS Feridos no Desastre. Folha da Manhã, 11 out. 1955, p.8.

JOÃO ANTONIO. Suor e cebola na Barra Funda. O Estado de São Paulo, 29 nov. 1986, p.91-92.

MORREU em consequencia da agressão. Folha da Manhã, 20 out. 1955, p. 6.

PREFEITURA MUNICIPAL DE SÃO PAULO. Decreto $n^{\circ} 647$ de 14 de julbo de 1946 . São Paulo: Prefeitura Municipal de São Paulo, 1946. 
PREFEITURA MUNICIPAL DE SÃO PAULO. Lei $n^{\circ} 2.877$ de 18 de junbo de 1925. São Paulo: Prefeitura Municipal de São Paulo, 1925.

PREFEITURA MUNICIPAL DE SÃO PAULO. Lei $n^{\circ} 4.845$ de 17 de dezembro de 1955 . São Paulo: Prefeitura Municipal de São Paulo, 1955.

PREFEITURA MUNICIPAL DE SÃO PAULO. SECRETARIA DE OBRAS. DEPARTAMENTO DE OBRAS. DIVISÃO DE PROJETOS. OBRAS 1. Ante-projeto Viaduto Pacaembu. Planta e Fachada Locação. Escala 1:200. Desenho n 18.416. São Paulo: PMSP, Arquivo da Divisão de Obras de Sistema Viário e Estruturas “Obras 3", 7 nov. 1956.

PREFEITURA MUNICIPAL DE SÃO PAULO. SECRETARIA DE OBRAS. DEPARTAMENTO DE OBRAS. DIVISÃO DE PROJETOS. OBRAS 1. Viaduto Pacaembu. Relocação dos pilares entre as ferrovias. Escala 1:200. Desenho n 19.570. São Paulo: PMSP, Arquivo da Divisão de Obras de Sistema Viário e Estruturas "Obras 3", 26 maio 1957.

RICARDO JUNIOR, Gaspar (Eng.). Relatório sobre os serviços ferroviário e rodoviário da Estrada de Ferro Sorocabana referente ao ano de 1932 pelo Eng. Gaspar Ricardo Junior Diretor. São Paulo: Tipografia Brasile de Rothschild\& Cia., 1933.

VIADUTO inaugurado pelo prefeito. O Estado de S.Paulo, São Paulo, 03out. 1958, p.17.

LIVROS, ARTIGOS E TESES

AMADO, Filipe. Abre a roda minha gente que o batuque é diferente: tiririca, capoeira e samba em São Paulo 1900-1970.2019. Dissertação (Mestrado) - Instituto de Estudos Brasileiros (IEB) da Universidade de São Paulo (USP), São Paulo, 2019.

AZEVEDO, Amailton Magno. A memória musical de Geraldo Filme os sambas e as microáfricas em São Paulo. 1927-1995.2014. Dissertação (Mestrado) - Departamento de História da Pontifícia Universidade Católica de São Paulo, São Paulo, 2006.

BORIN, Monique Félix. A Barra Funda e o fazer da cidade: experiências da urbanização em São Paulo (1890-1920).2014. Dissertação (Mestrado) - Faculdade de Filosofia, Letras e Ciências Humanas da Universidade de São Paulo (FFLCH-USP), São Paulo, 2014.

BRITTO, Iêda Marques. Samba na cidade de São Paulo (1900-1930): um exercício de resistência cultural. 1986. Dissertação (Mestrado) - Faculdade de Filosofia, Letras e Ciências Humanas da Universidade de São Paulo (FFLCH-USP), São Paulo, 1986. 
CABRAL, Muniz Sodré de A. O terreiro e a cidade: a forma social negro-brasileira. Rio de Janeiro: Vozes, 2002.

CISCATI, Márcia Regina. Malandros na terra do trabalbo: malandragem e boemia na cidade de São Paulo (1930-1950). São Paulo: Annablume/ Fapesp, 2001.

CONTI, Lígia Nassif. A memória do samba na capital do trabalbo: os sambistas paulistanos e a construção de uma singularidade para o samba de São Paulo. 2011. Tese (Doutorado) - Faculdade de Filosofia, Letras e Ciências Humanas da Universidade de São Paulo (FFLCHUSP), São Paulo, 2015.

CUNHA, Pedro Figueiredo Alves da. Capoeiras e valentões na história de São Paulo. 2011. Dissertação (Mestrado) - Faculdade de Filosofia, Letras e Ciências Humanas da Universidade de São Paulo (FFLCH-USP), São Paulo, 2011.

DOMINGUES, Petrônio. O campeão do centenário: raça e nação no futebol paulista. História Unisinos,v. 19, n. 3, set-dez/2015, p.368-376.

DOMINGUES, Petrônio. O triduo da loucura: Campos Elíseos e o carnaval afro-diaspórico. Tempo, v.19, n.35, 2013, p.117-142.

GOMES DA SILVA, José Carlos. Os sub urbanos e a outra face da cidade. Negros em São Paulo 1900-1930 - cotidiano, lazer e cidadania.1990. Dissertação (Mestrado) - Instituto de Filosofia e Ciências Humanas da Unicamp, Campinas, 1990.

FERREIRA, Abilio (org.). Tebas: um arquiteto negro na São Paulo escravocrata (abordagens). São Paulo: IDEA, 2018.

FERREIRA DOS SANTOS, Carlos José. Nem tudo era italiano: SãoPaulo e pobreza 1890-1915. São Paulo: Annablume, Fapesp, 1998.

GARCIA, Walter. Notas sobre Cálice (2010, 1973, 1978, 2011). Música popular em revista, Campinas, ano 2, v.2, jan-jun 2014, p.110-150.

GUIMARÃES, Antonio Sérgio Alfredo; MACEDO, Márcio. Diário Trabalhista e democracia racial negra dos anos 1940.Dados [on-line]. 2008, vol.51, n.1, p.143-182. Disponível em: <https://bit.ly/3abzM62>.Acesso em: 27 fev. 2020.

HERTZMAN, Marc A. Making Samba: A New History of Race and Music in Brazil.Bogart, Georgia: Duke University, 2013. 
MARCHEZIN, Lucas Tadeu. Um samba nas quebradas do mundaréu: a história do samba paulistano nas vozes de Geraldo Filme, Zézinho da Casa Verde, Toniquinho Batuqueiro e Plínio Marcos. 2016. Dissertação (Mestrado) - Instituto de Estudos Brasileiros da Universidade de São Paulo, São Paulo, 2016.

MORAES, José Geraldo Vinci de. Sonoridades Paulistanas: final do século XIX ao início do século XX. Rio de Janeiro: Funarte, 1997.

MORAES, Wilson Rodrigues de. Escolas de samba de São Paulo (capital). São Paulo: Conselho Estadual de Artes, 1978.

NASCIMENTO, Larissa A.C. do. Entre sambas e rezas: vivências, negociações e ressignificação da cultura afrobrasileira no Bexiga. 2015. Dissertação (Mestrado) Universidade Federal de São Carlos, São Carlos, 2015.

OLIVEIRA, Reinaldo José de. Segregação Urbana e Racial na Cidade de São Paulo: as periferias de Brasilândia, Cidade Tiradentes e Jardim Ângela. 2008. Tese (Doutorado) - Pontifícia Universidade Católica de São Paulo(PUC-SP), São Paulo, 2008.

OLIVEIRA SANTOS, Augusto. "Vai graxa ou samba, senhor?" A música dos engraxates paulistanos.2015. Dissertação (Mestrado) - Departamento de História da Faculdade de Filosofia, Letras e Ciências Humanas da Universidade de São Paulo, São Paulo, 2015.

OLIVEIRA SANTOS, Augusto. O "batuque dos engraxates" e o jogo da "tiririca": duas culturas de rua paulistanas. In: XXVII Simpósio Nacional de História. Associação Nacional de História, Natal, 2013.

PRADO, Bruna Queiroz. A passagem de Geraldo Filme pelo "samba paulista": narrativas de palavras e músicas. 2013. Dissertação (Mestrado) - Instituto de Filosofia da Universidade Estadual de Campinas, Campinas, 2013.

QUINTÃO, Antônia Aparecida. Irmandades negras: outro espaço de luta e resistência (São Paulo: 1870-1890). São Paulo: Annablume /Fapesp, 2002.

RAGO, Margareth. A invenção do cotidiano na metrópole: sociabilidade e lazer em São Paulo. In: PORTA, Paula (org.). História da Cidade de São Paulo (vol.III).São Paulo: Paz e Terra, 2004.

ROLNIK, Raquel. A cidade e a lei: legislação, política urbana e territórios na cidade de São Paulo. São Paulo: Nobel: Fapesp, 2003. 
ROLNIK, Raquel.Territórios Negros nas Cidades Brasileiras (etnicidade e cidade em São Paulo e Rio de Janeiro).Revista de Estudos Afro-asiáticos, 17, CEEA, Universidade Cândido Mendes, set/1989.

SILVA, Marcos Virgílio da. Debaixo do "Pogréssio". Urbanização, cultura e experiência popular em João Rubinato e outros sambistas paulistanos (1951-1969). 2011. Tese (Doutorado) Faculdade de Arquitetura e Urbanismo da Universidade de São Paulo, São Paulo, 2011.

SILVA, Marcos Virgílio da. A cidade de São Paulo de acordo com Robert Moses e Geraldo Filme. In: Congresso da Associação de Estudos Latino-Americanos, Barcelona, 2018.

SIQUEIRA, Renata M. Largo da Banana: um estudo do urbanismo paulistano sob uma perspectiva racializada. In: I Seminário "A Cidade e a Sujeição Racial". Apresentação de trabalho. São Paulo: LABRAÇA-FAUUSP, 2017.

SOUKEF JR., Antonio. Sorocabana: uma saga ferroviária. São Paulo: Imprensa Oficial, 2001.

TRAMONTINO, Vânia Silva. O espaço livre na vida cotidiana. Dissertação (Mestrado) Faculdade de Arquitetura e Urbanismo da Universidade de São Paulo, São Paulo, 2011.

WILLIAMS, Raymond. Palavras-chave: um vocabulário de cultura e sociedade. São Paulo: Boitempo, 2007.

\section{ENTREVISTAS}

BARBOSA, Dionísio. [Entrevista cedida a] José Ramos Tinhorão. Acervo Online do Museu da Imagem e do Som de São Paulo, 20 nov. de 1976. Disponível em: <https://bit.ly/2uAYbD7>. Acesso em: 27 fev. 2020.

EZEQUIEL, Mário (Tio Mário). [Entrevista cedida a] Filipe Amado, 2017. (não publicada).

FAUSTINO, Oswaldo. [Depoimento cedido a] Ana Cláudia Castilho Barone, set. 2018 (não publicado).

NAZARÉ, José Narciso de (Zezinho da Casa Verde).[Entrevista cedida a] Olga Rodrigues de Moraes Von Simson. Acervo Online do Museu da Imagem e do Som de São Paulo, 9 abr. 1981. Disponível em: <https://bit.ly/382js67>. Acesso em: 27 fev. 2020. 
SOUZA, Geraldo Filme de.[Entrevista cedida a] Olga Rodrigues de Moraes Von Simson. Acervo Online do Museu da Imagem e do Som de São Paulo, 27 maio 1981. Disponível em: <https:// bit.ly/2T5Bb8L>. Acesso em: 27 fev. 2020.

DOCUMENTOS AUDIOVISUAIS

SOUZA, Geraldo Filme. Geraldo Filme. São Paulo: Estúdio Eldorado, 1980 (documento audiovisual).

SOUZA, Geraldo Filme. A música brasileira deste século por seus autores e intérpretes. São Paulo: SESC-SP, 2000 (documento audiovisual).

Artigo apresentado em 26/03/2019. Aprovado em 19/12/2019.

(cc) BY

All the contents of this journal, except where otherwise noted, is licensed under a Creative Commons Attribution License 